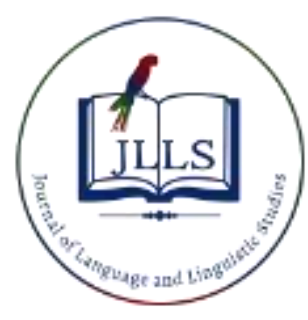

Available online at www.jlls.org

JOURNAL OF LANGUAGE AND LINGUISTIC STUDIES

ISSN: $1305-578 \mathrm{X}$

Journal of Language and Linguistic Studies, 16(1), 01-13; 2020

\title{
The effect of recorded oral feedback on EFL learners' writing
}

\author{
Mehdi Solhi a 1 (iD), İlknur Eğinli ${ }^{\text {b }}$ \\ ${ }^{a}$ Istanbul Medipol University, Istanbul 34815, Turkey \\ ${ }^{b}$ Istanbul Medipol University, Istanbul 34815, Turkey

\section{APA Citation:}

Solhi, M., \& Eğinli, I. (2020). The effect of recorded oral feedback on EFL learners' writing. Journal of Language and Linguistic Studies, 16(1), 01-13. Doi: 10.17263/jlls.712628

Submission Date: $12 / 27 / 2019$

Acceptance Date:01/21/2020

\begin{abstract}
While there is general agreement among learners, teachers, and scholars that constructive feedback on writing is necessary to revision, there are fewer consensuses on how feedback should be given, when, by whom, and what sort of feedback is most effective (Weigle, 2014). Providing feedback on writing is generally categorized into three types: written comments, individual conferences, and recorded oral feedback. As the first two types are believed to be very time-consuming and lots of workloads, recording comments, along with the advances in technology over the last decades, has opened new possibilities for feedback in the form of podcasts or other digitally recorded means. In this study, the effect of recorded oral feedback to the writing of the English as a foreign language (EFL) learners was taken into scrutiny. In so doing, two different types of feedback (i.e., audio-recorded comments and metalinguistic written corrective feedback) were given to the learner writing in two groups respectively. The treatment lasted for approximately two months, in which the participants received two different types of feedback to their writing (e.g., recorded oral feedback and metalinguistic written corrective feedback). Results indicated that the group receiving audio-recorded comments on their writing outperformed the latter in their content, and organization, while no significant difference was observed between the two groups in clarity and sentence-level accuracy.
\end{abstract}

(C) 2020 JLLS and the Authors - Published by JLLS.

Keywords: teacher feedback; recorded oral feedback; metalinguistic written feedback

\section{Introduction}

Corrective feedback in writing refers to constructive explanations on the appropriateness or accuracy of students writing, aiming to enhance their writing ability and teach effective writing to them. Giving feedback to students writing is believed to be necessary to improve students' skills and knowledge (Issa, Isaias, \& Issa, 2014) is probably the most important duty of a writing teacher and perhaps the most timeconsuming endeavor on the part of the teacher (Cavanaugh \& Song, 2014). Although it is unanimously agreed by learners, instructors, and scholars that providing good feedback is necessary to revision, establishing a mutual consensus "on how feedback should be given, when, by whom, and what sort of feedback is most useful" has not always been possible (Weigle, 2014, p. 232). As Ashwell (2000, p. 2)

\footnotetext{
${ }^{1}$ Corresponding author. Tel.: +90-216-681-5100/1717

E-mail address: solhi.mehdi@gmail.com
} 
states, many writing instructors correct the grammar of their students' writing, believing that "this will help them improve the accuracy of subsequent writing". However, focusing heavily on the accuracy of texts deprives writing of its communicative function and turns a writing class into a grammar class. In fact, a premature focus on language may hinder students' signs of progress of idea generation (Weigle, 2014). Despite the natural tendency of the writing instructors to focus primarily on sentence-level accuracy, some scholars (e.g., Ferris \& Hedgcock, 2004; Williams, 2005) argue for providing feedback primarily on the content before commenting on language issues. As it is practically unfeasible to address each issue in student writing, how to deal with student writing is an important issue to be thoroughly considered. Many scholars recommend, as Weigle (2014, p. 12) states, "prioritizing errors that interfere with comprehension, errors that are stigmatized, errors that are current focus of instruction, and errors that occur frequently".

Ellis (2009) categorizes written corrective feedback (WCF) into six broad areas: direct (i.e., directly providing the student with the correct form), indirect (i.e., indicating that an error exists without necessarily providing the correction), metalinguistic (i.e., providing learners with explicit comment or using error codes), focused versus unfocused (i.e., attempting to correct all or most of the students' errors, or purposefully selecting one or two specific types of errors to correct), electronic feedback (i.e., indicating an error and providing a hyperlink to a file that incorporates examples of correct usage, and finally reformulation (i.e., a native speaker's reworking of the students' entire text to make the language look as native-like as possible). Providing WCF to student's production, as Weigle (2014) elaborates, can be conducted in three ways: written comments, individual conferences, and recorded oral feedback. The written comments refer to providing endnotes, margin comments on learners' written script to reinforce the strength of a paper or indicate where improvement is required. This type of giving feedback to student's production is probably the most typical form of feedback to writing (Dalton, 2018). In the individual conferencing, the feedback is given to clarify and negotiate the strengths and weaknesses of the paper through discussion. This can be conducted during the class sessions (Bitchener \& Knoch, 2009), in the office or even outside the school. In recorded oral feedback, the oral comments are verbally or visually recorded feedback while reviewing the student's production and shared through a platform with the student.

Despite the popularity of written feedback to student writing, providing WCF, as Weigle (2014) believes, is open to misinterpretations or different interpretations of the comments given by the teacher, and generally is "undecipherable" in LaFontana's (1996, p. 71) word. A long amount of time spent on providing written feedback to student's writing is another potential drawback attributed to written comments (Ferris, 2007). However, the benefit in individual conferences, in contrast to written feedback, is that there is an interaction between the instructor and learners, which is quite effortful to establish through written feedback. Although individual conferencing is believed to be less time-consuming in comparison to providing written comments to student writing, this may not be practically possible in some settings, if there are no office hours, or the teacher/student is not available outside classroom. Besides, individual conferencing may not be an efficient option in crowded classes (Bakla, 2018). However, over the last decades, new developments in technology have paved the way for new audiorecording possibilities to particularly give feedback to writing in the forms of podcasts or other digitally recorded means. The advantages of recording comments to give feedback, as Weigle (2014) states, are several. First, it is generally faster and easier for teachers to state their comments orally than in writing. Second, unlike written comments and individual conferencing, students can listen to the recorded comments several times and it can be an additional practice in listening comprehension. Third, the oralaural channel and nonverbal information such as tone of voice and pitch can promote a positive interpretation of comments. The advocates of audio feedback postulate that this type of feedback results in more personalized communication and high student satisfaction (Ice, Curtis, Phillips, \& Wells, 2007), 
is more comprehensible and personal (Merry \& Orsmond, 2008), enables the instructor to focus more on content and meaning than use of language, helps self-monitoring, and is encouraging (Morra \& Asís, 2009), tends to be more flexible and user-friendly (Issa, Isaias, \& Issa, 2014), and is more time-efficient as it was reported in a study that "one-minute talking equals six minutes writing" (Lunt \& Curran, 2010, p. 3).

\subsection{Literature review}

The studies on the integration of audio feedback date back to the early 1970s when writing teachers used cassette tapes to give audio feedback to the students' writing (e.g., Klammer, 1973; Kahrs, 1974; Logan et al., 1976; Hays, 1978). Later, with the emergence of the digital revolution in technology in the 1990s, digital audio feedback to writing began to emerge (e.g., Pearce \& Ackley, 1995; LaFontana, 1996; Anson, 1997). During the last half-century, a considerable number of studies have been investigated on the effectiveness of audio-recorded feedback to the writing of the students (e.g., Kelly \& Ryan, 1983; Kirschner, van den Brink, \& Meester, 1991; Moxley, 1989; LaFontana, 1996; Huang, 2000; Stern \& Solomon, 2006; Silva, 2012; Cavanaugh \& Song, 2014; Li \& Vuono, 2019).

Stern and Solomon (2006) analyzed the feedback and comments given by the university instructors to approximately 600 papers assigned for a significant number of courses in different departments at a university. Most comments were reported to be mechanical corrections that addressed spelling, grammar, word choice, and missing words, while the overall comments on the organization and expansion of the ideas were simply insufficient. They believe that despite the importance of the smaller mechanical issues in writing, the overreliance on them and the absence of the holistic ideas and argumentation-based comments given by the instructors are likely to restrain a student from developing the quality of the global issues in writing.

\subsubsection{Recorded oral feedback to writing}

Silva (2012) examined the perceptions of the learners and their attitudes toward two different types of media-aided teacher feedback: Microsoft Word comments versus visual/audio commentary. The quality of the conversations, clear explanations of the expectations, and remarks to more global issues in writing were stated by the learners who preferred the visual/audio-aided teacher feedback. On the other hand, the ones who preferred the Microsoft Word comments were reported to more easily do surface-level revisions or spot the problematic sentences. Cavanaugh and Song (2014) similarly investigated learners' and teachers' beliefs on audio and written feedback for students writing in online composition classes. Results indicated that teachers tend to provide more general comments when utilizing audio platforms but more detailed comments when giving feedback to the writing of the students. Students also were reported to have positive feelings toward the integration of audio while obtaining feedback for their writing. In a different study, Issa, Isaias, and Issa (2014) also examined students' perceptions about the writing feedback provided through the traditional Microsoft Word application and the MP3 audio feedback given through Audacity, i.e. multilingual audio editor and recorder software. Most of the participants confirmed that audio feedback to their writing helped their understanding of course content and improved their learning skills.

Ice, Curtis, Phillips, and Wells (2007) investigated the utilization of audio feedback and its effectiveness in asynchronous courses. Results indicated that audio feedback was more effective than text-based feedback for conveying subtleties. Along with increased involvement and enhanced learning community interactions between the students and the teacher, audio feedback was associated with increased retention of content. The analysis of the documents indicated that learners receiving audio commenting were three times more likely to apply content than their counterparts for which the feedback was text-based. Lunt and Curran (2010) studied the efficacy of audio feedback with a group of students 
who received feedback through Audacity. The results revealed that the students felt a positive feeling of being more involved when receiving audio feedback. Morra and Asís (2009) examined the effectiveness of on-tape, written, and that of no feedback on 89 students' error correction. A comparison of the number of macro (content, organization) and micro (vocabulary, grammar, mechanics) errors in five of the six groups indicated a significant reduction in the number of mistakes in final drafts. Both taped and written feedbacks were perceived to have been beneficial in revision, the most useful aspect of teacher feedback was reported to have been a focus on micro errors. However, the Translation Studies group, whose received feedback was on-tape, revealed negative changes at the micro-level. In fact, there was an increase in the number of micro errors after the treatment.

However, Macgregor, Spiers, and Taylor (2011) evaluated the efficacy of audio feedback in formative assessment and consequently on students' learning, using Wimba Voice ${ }^{\mathrm{TM}}$, i.e., a web-based platform that possesses a series of audio tools such as a podcaster and voice-enabled discussion fora. They indicated that the group not receiving audio feedback outperformed the treatment group who received feedback in learning tasks were audio-taped. As a result, statistically no significant difference was reported between the groups. Neither was there any indication of improvements in the learning of the experimental group. In a similar vein, Johnson and Cooke's (2015) study also revealed the students' preference for written corrective feedback. Investigating the relationships between distance education students' level of self-regulated learning and their preference for audio-recorded versus written feedback, Johnson and Cooke (2015) indicated that distance education learners stated preference for written over audio-recorded feedback. Distance education learners who preferred listening to audio-recorded feedback appreciated peer interaction and personal challenges more than those who preferred written feedback. Demerits of audio feedback were reported to be the large size of the audio files (up to $11 \mathrm{Mb}$ ) being incompatible with some e-mail systems (Merry \& Orsmond, 2008). Besides, as Morra and Asís (2009) assert, students may focus more on listening than on comments, and the ones with deficient listening skills may be at a disadvantage.

As a type of digitally recorded mean, the efficacy of video-feedback has been also investigated. Özkul and Ortaçtepe (2017) examined the effectiveness of video feedback in teaching process-approach EFL writing. Results indicated that video-mediated feedback was more effective than written feedback when the participants in the experimental group revised their production in process writing. They were reported to outperform their counterparts in the control group in correcting their subsequent drafts. Özkul and Ortaçtepe (2017) argue in favor of utilization of technologic computer tools such as screencasts to enhance the efficiency of corrective feedback in writing instruction. They believe that video-capture tools by which the teachers record videos to give feedback and offer corrections to the writing of the students are more likely to pave the way for language learners to increase their writing skill. Screencast is a tool for digital recording of computer screen output that has attracted considerable attention as a way of providing video feedback on student's writing (e.g., Hynson, 2012; Moore \& Filling, 2012, Silva, 2012; Ali, 2016; Ghosn-Chelala \& Al-Chibani, 2018). As Bakla (2018) indicates, through this user-friendly platform writing instructors can provide constructive feedback through recording the screen when commenting on student's writing and editing it, which enables the nature of feedback to go beyond the restrictions of physical space and time in.

\subsection{Research questions}

Despite the number of studies on the effectiveness of audio feedback in writing, few researchers have attempted to measure student learning to better understand audio feedback efficacy (Macgregor, Spiers, $\&$ Taylor, 2011). This study with the focus on different categories of writing (i.e., content, organization, style, and mechanics) has made an attempt to better understand the efficacy of audio-feedback on student writing. In so doing, the following research question was formulated: 
Does recorded oral feedback yield improvement in the writing of EFL learners?

\section{Method}

\subsection{Sample / Participants}

A total of 51 university students enrolled in B2 level (i.e., intermediate) classes at an English preparatory program of an English-medium Turkish university participated in this study. The average age of the participants was 17 to 27. Their intermediate level of English had already been identified through a standardized placement test and language measurement proficiency exam of the university respectively. After being placed in different classes and conveniently selecting two classes, the first one class with 27 learners was randomly selected to be the control group and the other one with 24 was chosen as the experimental group of the study.

\subsection{Data collection procedures}

This study does not require ethics committee approval. In this study, writing an opinion essay was introduced in two writing classes, whose received feedback was recorded oral feedback for the experimental group and metalinguistic WCF for the control group. For each student, the phases of the writing process (Seow, 2002) were followed. The phases of writing (Figure 1.) as a classroom activity incorporates four basic stages (i.e., planning, drafting, revising, and editing), and three accompanying stages (i.e., responding, evaluating, and post-writing). The first stage is planning that encompasses thought-stimulating activities for getting started. It can be group brainstorming, clustering, rapid free writing, and generating wh- questions to come up with more ideas before going to the following step, drafting. After gathering sufficient ideas at the second stage, the students pay more attention to the fluency of writing, not preoccupied with the accuracy and neatness of the draft. Before proceeding to the third stage, revising, the teacher's quick initial reaction to students' drafts is provided at the first intervening stage: responding stage. This initial feedback can be written or oral. After that, students are expected to revise their writing based on the feedback received at the first intervening stage. At the revising stage, global content and organization of ideas are also taken into consideration, rather than only focusing on checking for language errors. At the fourth stage, editing, students are more involved with tidying up their texts as they prepare the final draft for evaluation by the teacher. At this stage, they also look at the accuracy as well as the discourse of the writing. Then the following two intervening stages, evaluating and post-writing stages, come respectively. In the former stage, the student writing is analytically or holistically evaluated using a criteria, and in the latter, the writing can be considered for, say, publishing or displaying.

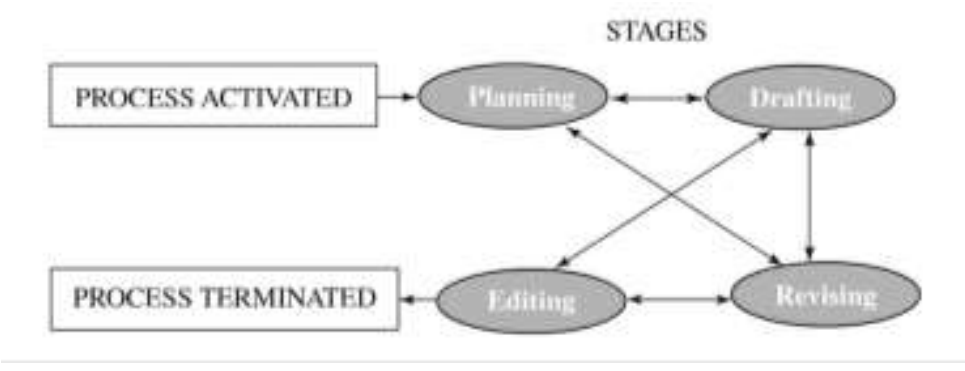

Figure 1. The writing process 
In a typical implementing of the writing process, after brainstorming the ideas (i.e. planning), at the drafting stage, the learners were asked to focus on the fluency of writing and were asked not to be preoccupied with grammatical accuracy or the neatness of the draft. It was at the responding stage that the students in both groups received two different types of feedback (i.e., recorded oral feedback and metalinguistic WCF) for writing. Their writing class took for two hours a week and lasted for eight weeks. When they produced their writing at the end of the second stage each week, the teacher collected their pieces of writing and gave feedback to the experimental group using Telegram, a free and fast application for messaging, file sharing, and calling. In order to use this application, the teacher is not required to share his/her phone number with the students and sharing the username is sufficient in order to be able to communicate on this platform. The topics of the writing in both classes were the same and the students worked on writing an opinion essay in their writing classes. At the end of the term, they produced at least 7 opinion essays based on the two different types of feedback (i.e., recorded oral feedback and metalinguistic WCF) they received from the same teacher. After receiving the feedback, at the revising phase and editing respectively, the learners were supposed to make the required changes based on the feedback received. Finally, in the last phase, their edited essays were evaluated and put in the portfolio to keep track of the learners' progress.

The essay assessment rubric used to assess the writings of the students comprised of four categories (25 points for each category): content, organization, style, and mechanics (sentence-level accuracy). In content, clarity and appropriateness of the stated main and supporting ideas in the paragraphs were the focus of attention. In the organization, the structure and organization of the different sections of the essay (i.e., introduction, body, and conclusion) were taken into consideration. In style, how smooth, coherent, and consistent the writing was, and the strength and expressiveness of the sentences were thoroughly evaluated. In mechanics category, accuracy in word selection and use, sentences structure, spelling, punctuation, and capitalization were the subjects of attention and assessment.

\section{Results}

At the outset, a pre-test, in which the students were supposed to write an opinion, was administered to assure the homogeneity of the participants in both groups before conducting the treatment. The nominal time for the exam was 80 minutes. The content, organization, style, and mechanics of the students writing were assessed using the revised Pamela's essay assessment rubric. An independent ttest analysis of variance between the two groups (Table 1) indicated that there was not a significant difference between the scores of the participants in the control $(\mathrm{M}=17.18, \mathrm{SD}=2.86)$ and the experimental $(\mathrm{M}=16.62, \mathrm{SD}=3.06)$ groups in their content $t(49)=.674, p<.503$. Nor was there a significant difference between the control $(\mathrm{M}=15.14, \mathrm{SD}=2.69)$ and the experimental $(\mathrm{M}=14.83, \mathrm{SD}=$ 1.97) groups in organization of their writing $t(49)=.670 p<.640$. The results also did not indicate a significant difference for style of the control group $(\mathrm{M}=15.25, \mathrm{SD}=2.63)$ and the experimental group $(\mathrm{M}=17.33, \mathrm{SD}=3.11) t(49)=-2.57, p<.013$, nor for mechanics of the control $(\mathrm{M}=15.85, \mathrm{SD}=3.00)$ and the experimental group $(\mathrm{M}=17.58, \mathrm{SD}=3.53), t(49)=-1.889, p<.065$. 
Table 1. T-test results between the control and the experimental groups' pretests

\begin{tabular}{|c|c|c|c|c|c|c|c|}
\hline & & $\mathbf{F}$ & Sig. & $\mathbf{t}$ & df & Sig. (2-tailed) & MD \\
\hline \multirow[t]{2}{*}{ Content } & $\begin{array}{l}\text { Equal variances } \\
\text { Assumed }\end{array}$ & .024 & .878 & .674 & 49 & .503 & .560 \\
\hline & $\begin{array}{l}\text { Equal variances } \\
\text { not assumed }\end{array}$ & & & .672 & 47.38 & .505 & .560 \\
\hline \multirow[t]{2}{*}{ Organization } & $\begin{array}{l}\text { Equal variances } \\
\text { Assumed }\end{array}$ & 1.61 & .209 & 470 & 49 & .640 & .314 \\
\hline & $\begin{array}{l}\text { Equal variances } \\
\text { Not assumed }\end{array}$ & & & .479 & 47.30 & .634 & .314 \\
\hline \multirow[t]{2}{*}{ Style } & $\begin{array}{l}\text { Equal variances } \\
\text { Assumed }\end{array}$ & 2.357 & .131 & -2.573 & 49 & .013 & -2.07 \\
\hline & $\begin{array}{l}\text { Equal variances } \\
\text { Not assumed }\end{array}$ & & & -2.548 & 45.37 & .014 & -2.07 \\
\hline \multirow[t]{2}{*}{ Mechanics } & $\begin{array}{l}\text { Equal variances } \\
\text { Assumed }\end{array}$ & 1.700 & .198 & -1.889 & 49 & .065 & 1.73 \\
\hline & $\begin{array}{l}\text { Equal variances } \\
\text { Not assumed }\end{array}$ & & & -1.871 & 45.46 & .068 & -1.73 \\
\hline
\end{tabular}

Then, to investigate whether the treatment (i.e., recorded oral feedback) yielded improvement in writing of the students, a post-test (i.e., an opinion essay) was administered as a post-test to the students. After that, an independent samples t-test was applied to examine the possible significant difference between the two groups and to assess the possible improvement. The results obtained from the t-test run (Table 2 and Table 3) for the control group and the experimental group showed a significant difference between the scores of the students in the control group $(\mathrm{M}=18.55, \mathrm{SD}=2.93)$, and that of the experimental group $(\mathrm{M}=21.66, \mathrm{SD}=1.37), t(49)=-4.74, p<.000$ for the content of writing. The effect size calculated for the content $(d=-1.35)$ was very large. There was also a significant difference in organization of writing between the control $(\mathrm{M}=18.70, \mathrm{SD}=2.19)$ and the experimental groups $(\mathrm{M}=$ 21.66, $\mathrm{SD}=1.30), t(49)=-5.75, p<.000$. The effect size of the organization $(d=-1.64)$ was indicated to be very large. However, no significant difference was observed between the scores of the control group $(\mathrm{M}=21.66, \mathrm{SD}=1.30)$ and the experimental group $(\mathrm{M}=17.44, \mathrm{SD}=3.27), t(49)=-.907, p<$ .369 in style of writing. Nor was there any significant difference between the control $(\mathrm{M}=20.18, \mathrm{SD}=$ $2.09)$ and the experimental $(\mathrm{M}=19.75, \mathrm{SD}=2.28)$ groups in the mechanics of writing, $t(49)=.709, p$ $<.482$. The effect size calculated for style and mechanics was $d=-0.25$ and $d=0.19$ respectively.

Table 2. Descriptive statistics for the post-test

\begin{tabular}{llllll}
\hline \multicolumn{1}{c}{ Group } & N & Mean & SD & \\
\hline \multirow{2}{*}{ Content } & Control & 27 & 18.55 & 2.93 \\
& Experimental & 24 & 21.66 & 1.37 \\
\multirow{2}{*}{ Organization } & Control & 27 & 18.70 & 2.19 \\
& Experimental & 24 & 21.66 & 1.30 \\
Style & Control & 27 & 17.44 & 3.27 \\
& Experimental & 24 & 18.29 & 3.39 \\
Mechanics & Control & 27 & 20.18 & 2.09 \\
& Experimental & 24 & 19.75 & 2.28 \\
& & & & \\
\hline
\end{tabular}


Table 3. T-test results between the control and the experimental groups' post-tests

\begin{tabular}{|c|c|c|c|c|c|c|c|}
\hline & & $\mathbf{F}$ & Sig. & $\mathbf{t}$ & df & Sig. (2-tailed) & MD \\
\hline Content & $\begin{array}{l}\text { Equal variances } \\
\text { Assumed } \\
\text { Equal variances } \\
\text { not assumed }\end{array}$ & 22.57 & .000 & $\begin{array}{l}-4.74 \\
-4.92\end{array}$ & $\begin{array}{l}49 \\
37.75\end{array}$ & $\begin{array}{l}.000 \\
.000\end{array}$ & $\begin{array}{l}-3.11 \\
-3.11\end{array}$ \\
\hline Organization & $\begin{array}{l}\text { Equal variances } \\
\text { Assumed } \\
\text { Equal variances } \\
\text { Not assumed }\end{array}$ & 6.53 & .014 & $\begin{array}{l}-5.75 \\
-5.92\end{array}$ & $\begin{array}{l}49 \\
43.10\end{array}$ & $\begin{array}{l}.000 \\
.000\end{array}$ & $\begin{array}{l}-2.96 \\
-2.96\end{array}$ \\
\hline Style & $\begin{array}{l}\text { Equal variances } \\
\text { Assumed } \\
\text { Equal variances } \\
\text { Not assumed }\end{array}$ & .014 & .905 & $\begin{array}{l}-.907 \\
-.905\end{array}$ & $\begin{array}{l}49 \\
47.83\end{array}$ & $\begin{array}{l}.369 \\
.370\end{array}$ & $\begin{array}{l}-.84 \\
-.84\end{array}$ \\
\hline Mechanics & $\begin{array}{l}\text { Equal variances } \\
\text { Assumed } \\
\text { Equal variances } \\
\text { Not assumed }\end{array}$ & .035 & .852 & $\begin{array}{l}.709 \\
.705\end{array}$ & $\begin{array}{l}49 \\
46.96\end{array}$ & $\begin{array}{l}.482 \\
.484\end{array}$ & $\begin{array}{l}.435 \\
.435\end{array}$ \\
\hline
\end{tabular}

A Shapiro-Wilk's test ( $p>.05$ ) and a visual inspection of their histograms, normal Q-Q plots and box plots indicated that the scores of the content were approximately normally distributed for both the control and experimental groups, with a skewness of -.291 ( $\mathrm{SE}=.448)$ and a kurtosis of $-1.289(\mathrm{SE}=$ $.872)$ for the control group, and a skewness of .114 ( $\mathrm{SE}=.472)$ and a kurtosis of $-.554(\mathrm{SE}=.918)$ for the experimental group. The similar test also showed approximately normal distributions for the scores of organization, with a skewness of -.812 ( $\mathrm{SE}=.448)$ and a kurtosis of -.176 $(\mathrm{SE}=.872)$ for the control group, and a skewness of .174 ( $\mathrm{SE}=.472)$ and a kurtosis of -.144 ( $\mathrm{SE}=.918)$ for the experimental group. Similar to the scores of content and organization, those of style were also revealed to be approximately normally distributed for the both control and experimental groups, with a skewness of $.147(\mathrm{SE}=.448)$ a kurtosis of $-1.554(\mathrm{SE}=.872)$ for the control group, and a skewness of -.426 ( $\mathrm{SE}=.472)$ and a kurtosis of $-1.270(\mathrm{SE}=.918)$ for the experimental groups. The normal distributions of the scores are also seen for the mechanics of writing, with a skewness of $-.780(\mathrm{SE}=.448)$ and a kurtosis of $1.794(\mathrm{SE}=.872)$ for the control group, and a skewness of $-1.231(\mathrm{SE}=.472)$ and a kurtosis of $1.810(\mathrm{SE}=.918)$ for the experimental group.

\section{Discussion}

In general, the results indicated that both types of feedback were effective as the mean scores of both groups in the post-test were higher than those of the pre-test. However, the group receiving audiorecorded comments through Telegram on their writing outperformed the latter in their content and organization, while no significant difference was observed between the two groups in clarity and sentence-level accuracy. The mean scores of the three categorizations (i.e., content, organization, and style) were higher in the group receiving audio-recorded feedback, but it was only in the mechanics of writing that the mean score of the group receiving metalinguistic written corrective feedback for their writing was higher than that of the experimental group. However, the difference was not significant. Ice et al. (2007) investigated the utilization of audio feedback and its effectiveness in the courses. Results indicated that audio feedback was more effective than text-based feedback for conveying subtleties. 
Along with increased involvement and enhanced learning community interactions between the students and the teacher, audio feedback was associated with increased retention of content. The analysis of the documents indicated that learners receiving audio commenting were three times more likely to apply content than their counterparts for which the feedback was text-based. Different from Ice et al (2007), in the current study audio-feedback was not found to be more effective than text-based feedback when focused on subtleties (style and sentence-level accuracy).

In a different study, Morra and Asís (2009) examined the effectiveness of on-tape, written, and that of no feedback on 89 students' error correction. A comparison of the number of macro (content, organization) and micro (vocabulary, grammar, mechanics) errors in five of the six groups indicated a significant reduction in the number of mistakes in final drafts. Both taped and written feedbacks were perceived to have been beneficial in revision. Similar to Morra and Asis's (2009) study, both audiorecorded feedback and written feedback were effective in their final writing. However, audio-recorded feedback had more beneficial results than written feedback. Macgregor et al.'s (2011) study similarly indicated no significant difference between the group whose feedback was audio-taped and the one who did not receive audio feedback for their tasks. They evaluated the efficacy of audio feedback in formative assessment and consequently on students' learning, using Wimba Voice ${ }^{\mathrm{TM}}$. They indicated that the group not receiving audio feedback outperformed the treatment group who received feedback in learning tasks were audio-taped. As a result, statistically, no significant difference was reported between the groups. Neither was there any indication of improvements in the learning of the experimental group.

As Zheng (1999) noted acquiring writing skills in a second language seems to be more challenging than acquiring other language skills, more specifically writing a coherent piece of essay (Nunan, 1999). Leki (1991) asserts that rhetorical conventions of English texts- the structure, style, and organizationoften differ from those in other languages as they require a great effort to recognize and manage the differences. Feedback on writing plays a major role in teaching writing (Alvira, 2016), and the findings of the current study highlighted that recorded oral feedback in writing can enhance students' writing in terms of content and organization. In addition, despite the differences between oral and written corrective feedback, researchers in the field of second language acquisition have not revealed a premise that the written feedback leads to improvement in mechanic errors (Sheen, 2007). As it has been historically known that content was the first and the organization was the second most difficult constructs in grading writing papers (Freedman, 1979), the results of this study reveal that recorded oral feedback tends to have an impact on not only the content but also the organization of EFL learners' writing skills. Additionally, as opposed to highlighting linguistic errors in students' writing, our results indicated the importance of developing ideas and organization (Ferris, 2003).

\section{Conclusions}

Teachers often become frustrated both by the amount of the time that error correction takes and its seeming ineffectiveness. However, the advances in technology over the last decades have opened new possibilities for feedback in the form of podcasts or other digitally recorded means such as Telegram or WhatsApp. Özkul and Ortaçtepe (2017) also argue in favor of the integration of technologic tools to enhance the efficiency of corrective feedback in writing instruction. In this study, the utilization of Telegram, as a gadget to facilitate the process of giving feedback to writing, indicated to be more effective. Hopefully, by becoming attuned to English language teacher's challenging role especially when they are burdened with too much writing workload, teachers should be encouraged to use audio feedback with the help of technology on student writing since it is more likely to be welcomed by the students in an era where they are digital natives. With the audio-aided corrective feedback on their 
writing, the student could be more enthusiastic about their work when the teacher's focus is on the communication and comprehension of the given information rather than the correction of ungrammatical sentences (McGarrell \& Verbeem, 2007). Thus, the results of the current study provide further possible implications. Audio-recorded feedback provided for the EFL learners in an online environment has demonstrated improvement in students' two main categories of writing, namely content and organization, which promotes students' communication skills both in their personal and professional lives (Johnson \& Cooke, 2015).

The effect of audio feedback can be revealed via other technologic tools to enhance writing instruction. In addition, as Alvira (2016) indicates, in order for teachers to improve their skills in teaching writing and giving feedback more studies need to be conducted to clarify the differences between giving paper feedback and e-feedback on students' writing assignments. Needless to say, more research on examining the effect of using oral feedback at different language proficiency and education levels will enlighten both teachers and teacher educators.

\section{Ethics Committee Approval}

The authors confirm that the study does not need ethics committee approval according to the research integrity rules in their country. (Date of Confirmation: 12.03.2020)

\section{References}

Ali, A. D. (2016). Effectiveness of using screencast feedback on EFL students' writing and perception. English Language Teaching, 9(8), 106-121.

Alvira, R. (2016). The impact of oral and written feedback on EFL writers with the use of screencasts. PROFILE Issues in Teachers' Professional Development, 18(2), 79-92.

Anson, C. (1997). In our own voices: Using recorded commentary to respond to writing. In M. D. Sorcinelli \& P. Elbow (Eds.), Writing to learn: Strategies for assigning and responding to writing across the disciplines (pp. 105-113). San Francisco, CA: Jossey-Bass.

Bakla, A. (2018). An overview of screencast feedback in EFL writing: Fad or the future? Yabancı Dil Olarak Türkçe Öğretimi ve Yabancı Dil Öğretimi Araştırmaları, 319-331.

Bitchener, J., \& Knoch, U. (2009). The contribution of written corrective feedback to language development: A ten month investigation. Applied Linguistics, 31(2), 193-214.

Cavanaugh, J. L., \& Song, L. (3014). Audio feedback versus written feedback: Instructors' and students' perspectives. MERLOT Journal of Online Learning and Teaching, 10(1), 122-138.

Dalton, Z. J. (2018). The discourse of written and audio feedback (Unpublished MA thesis). Central Washington University.

Ferris, D. (2003). Responding to writing. In B. Kroll (Eds.), Exploring second language writing (pp. 119-140). Cambridge: Cambridge University Press.

Ferris, D. (2007). Preparing teachers to respond to student writing. Journal of Second Language Writing, 16(3), 165-193.

Freedman, S. (1979). How characteristics of student essays influence teachers' evaluations. Journal of Educational Psychology, 71(3), 328-338. 
Hays, J. (1978). Play it again, Sandra: The use of tape cassettes to evaluate student compositions. Paper Presented at the Annual Meeting of the Conference on College Composition and Communication (ERIC Document Reproduction Service No. ED 162332).

Hynson, Y. T. A. (2012). An innovative alternative to providing writing feedback on students' essays. Teaching English with Technology, 12(1), 53-57.

Ice, P., Curtis, R., Phillips, P., \& Wells, J. (2007). Using asynchronous feedback to enhance teaching presence and student sense of community. Journal of Asynchronous Leaning Networks, 11, 3-25.

Issa, T., Isaias, P., \& Issa, T. (2014). Does MP3 audio feedback enhance students' learning skills? An international case study. The International Journal of Learning, 19, 15-28.

Johnson, G. M., \& Cooke, A. (2015). Self-regulation of learning and preference for written versus audiorecorded feedback by distance education students. Distance Education, 37(1), 107-120.

Kelly, P., \& Ryan, S. (1983). Using tutor tapes to support the distance learner. International Council for Distance Education Bulletin, 3, 1-18.

Kirschner, P. A., van der Brink, H., \& Meester, M. (1991). Audiotape feedback for essays in distance education. Innovative Higher Education, 15(2), 185-195.

Klammer, E. (1973). Cassettes in the classroom. College English, 35(2), 179-181.

LaFontana, V. R. (1996). Throw away that correcting pen. English Journal, 85(6), 71-73.

Leki, I. (1991). Twenty years of constructive rhetoric: Text analysis and writing pedagogies. TESOL Quarterly, 25(1), 123-143.

Li, S., \& Vuono, A. (2019). Twenty-five years of research on oral and written corrective feedback in System, System, 84, 93-109.

Logan, H. L., Logan, N. S., Fuller, J. L., \& Denehy. G. E. (1976). The role of audiotape cassettes in providing student feedback. Educational Technology, 16(12), 38-39.

Lunt, T., \& Curran, J. (2010). Are you listening please? The advantages of electronic audio feedback compared to written feedback. Assessment and Evaluation in Higher Education, 35(7), 759-769.

Macgregor, G., Spiers, A., \& Taylor, C. (2011). Exploratory evaluation of audio email technology in formative assessment feedback. Research in Learning Technology, 19, 39-59.

McGarrell, H., \& Verbeem, J. (2007). Motivating revision of drafts through formative feedback. ELT Journal, 61(3), 228-236

Merry, S., \& Orsmond, P. (2008). Students' attitudes to and usage of academic feedback provided via audio files. Bioscience Education, 11(1), 1-11.

Moore, N. S., \& Filling, M. L. (2012). iFeedback: Using video technology for improving student writing. Journal of College Literacy \& Learning, 38, 3-14.

Morra, A. M., \& Asís, M. I. (2009). The effect of audio and written teacher responses on EFL student revision. Journal of College Reading and Learning, 39, 68-81.

Nunan, D. (1999). Second language teaching and learning. Boston: Heinle and Heinle Publishers.

Özkul, S., \& Ortaçtepe, D. (2017). The use of video feedback in teaching process-approach EFL writing. TESOL Journal, 8, 862-877.

Pearce, C. G., \& Ackley, R. J. (1995). Audiotaped feedback in business writing: An exploratory study. Business Communication Quarterly, 58(3), 31-34. 
Seow, A. (2002). The writing process and process writing. In J. C. Richards \& W. A. Renandya (Eds.), Methodology in language teaching: An anthology of current practice (pp. 315-320). The UK: Cambridge University Press.

Sheen, Y. (2007). The effect of focused written corrective feedback and language aptitude on ESL learners' acquisition of articles. TESOL Quarterly, 41, 255-283.

Silva, M. L. (2012). Camtasia in the classroom: Student attitudes and preferences for video commentary or Microsoft Word comments during the revision process. Computers \& Composition, 29(1), 1-22.

Stern, L. A., \& Solomon, A. (2006). Effective faculty feedback: The road less traveled. Assessing Writing, 11(1), 22-41.

Zheng, Y. (1999). Providing the students with effective feedback in the writing process. Teaching English in China, 36, 41-45.

\title{
İngilizce'yi yabanci dil olarak öğrenen öğrencilerin yazıları üzerine olan ses kayıtlı geri bildirimin etkisi
}

\begin{abstract}
$\ddot{O} \mathbf{z}$
Yazı yazma alanında yapıcı geri bildirim ile ilgili bir revizyon yapılması gerektiği görüşüne, öğrenciler, öğretmenler, ve araştırmacılar ortak olarak katılmasına rağmen, en etkili geri bildirimin ne, ne zaman, nasıl, ve kim tarafından verilmesi hakkında ortak bir görüş yoktur (Weigle, 2014). Yazı yazma alanında geri bildirim üç genel kategoriye ayrılmıştır: yazılı bildirimler, birebir konferanslar, ve kayıt edilen sözlü geri bildirim. İlk iki kategorideki yöntemler çok zaman aldığı ve iş yükü fazla olduğu için, son yıllarda hızla gelişen teknoloji sayesinde kayıt edilen geri bildirimler icin, podcast ve dijital kayıt araçları gibi araçlar sayesinde geri bildirim verme alanı yeni olanaklara kavuşmuştur. Bu çalışmada, ses kayıtlı geri bildirim tekniğinin etkisi İngilizce'yi yabanci dil olarak öğrenen öğrencilerin yazı yazma alanında kullanılarak incelenmiştir. İki değişik geri bildirim yöntemi iki benzer gruba uygulanmıştır. Bir gruba ses kayıtlı geri bildirim, diğer grup ise üstdilsel yazılı geri bildirimi yaklaşık olarak iki ay uygulanmıştır. İnceleme sonuçlarına göre, yazılarında ses kayıtlı geri bildirim alan öğrenciler içerik ve organizasyon alanında diğer grup öğrencilerine göre daha başarılı olurken, iki grup arasında cumle yapısı açısından bakıldığında anlaşırlık ve doğruluk alanında belirgin bir farklılığa rastlanmamıştır.
\end{abstract}

Anahtar sözcükler: öğretmen geri bildirimi; ses kayıtlı geri bildirim; üstdilsel yazılı geri bildirimi

\section{AUTHOR BIODATA}

Mehdi Solhi Andarab is an Assistant Professor in the Department of English Language Teaching at Istanbul Medipol University, Istanbul, Turkey. His research interests include Applied Linguistics, Teaching English as an International Language, Cultural Studies, Coursebook Evaluation, and Teaching Writing. His publications include articles in various refereed journals in the field. 
İlknur Eginli is an Assistant Professor in the Department of English Language Teaching at Istanbul Medipol University, Istanbul, Turkey. Her research interests center on Motivation, Second Language Acquisition, Assessment and Evaluation, Professional Development, and Quality of Education. 